\title{
A Review of Different Aspects of Applying Asphalt and Bituminous Mixes under a Railway Track
}

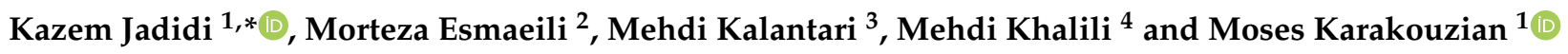 \\ 1 Howard R. Hughes College of Engineering, University of Nevada Las Vegas, Las Vegas, NV 89154, USA; \\ Mkar@unlv.nevada.edu \\ 2 School of Railway Engineering, Iran University of Science and Technology, Tehran 13114-16846, Iran; \\ m_esmaeili@iust.ac.ir \\ 3 Department of Civil Engineering, Roads Research Institute, D-57068 Siegen, Germany; \\ kalantari@bau.uni-siegen.de \\ 4 Geosyntec Consultants, Johnson City, TN 37601, USA; MKhalili@geosyntec.com \\ * Correspondence: Kazem.Jadidi@unlv.edu
}

check for

updates

Citation: Jadidi, K.; Esmaeili, M.;

Kalantari, M.; Khalili, M.;

Karakouzian, M. A Review of

Different Aspects of Applying Asphalt and Bituminous Mixes under a Railway Track. Materials 2021, 14,

169. https://doi.org/10.3390/

ma14010169

Received: 13 November 2020

Accepted: 18 December 2020

Published: 31 December 2020

Publisher's Note: MDPI stays neutral with regard to jurisdictional clai$\mathrm{ms}$ in published maps and institutional affiliations.

Copyright: (C) 2020 by the authors. Licensee MDPI, Basel, Switzerland. This article is an open access article distributed under the terms and conditions of the Creative Commons Attribution (CC BY) license (https:// creativecommons.org/licenses/by/ $4.0 /)$.

\begin{abstract}
Asphalt is a common material that is used extensively for roadways. Furthermore, bituminous mixes have been used in railways, both as asphalt and as mortar. Different agencies and research institutes have investigated and suggested various applications. These studies indicate the benefits of bituminous material under railways, such as improving a substructure's stiffness and bearing capacity; enhancing its dynamic characteristics and response, especially under high-speed train loads; waterproofing the subgrade; protecting the top layers against fine contamination. These potential applications can improve the overall track structure performance and lead to minimizing settlement under heavy loads. They can also guarantee an appropriate response under high-speed loads, especially in comparison to a rigid slab track. This review paper documents the literature related to the utilization of asphalt and bituminous mixes in railway tracks. This paper presents a critical review of the research in the application of asphalt and bituminous mixes in railway tracks. Additionally, this paper reviews the design and construction recommendations and procedures for asphalt and bituminous mixes in railway tracks as practiced in different countries. This paper also provides case studies of projects where asphalt and bituminous mixes have been utilized in railway tracks. It is anticipated that this review paper will facilitate (1) the exchange of ideas and innovations in the area of the design and construction of railway tracks and (2) the development of unified standards for the design and construction of railway tracks with asphalt and bituminous mixtures.
\end{abstract}

Keywords: railway; slab track; asphalt; bitumen; underlay; overlay; asphalt concrete; mortar 


\section{Contents}

1.

2.

2.1 .

2.2 .

2.3 .

3.

3.1.

3.2.

4.

5.

6.

6.1.

6.2.

6.3 .

6.4 .

7.

8.

References

$\begin{array}{rr}\text { Introduction } & 2 \\ \text { Asphalt Pavement Applications in Railway Track Support Systems } & 3 \\ \text { Asphalt in Ballasted Railway Tracks } & 4 \\ \text { Asphalt in Ballastless Tracks } & 4 \\ \text { Asphalt Mortar in Ballastless Track } & 6 \\ \text { Recommendations on the Mix Design of Asphalt for Railway Tracks } & 7 \\ \text { Volumetric Properties } & 7 \\ \text { Aggregate Gradation } & 9 \\ \text { Structural Properties of Asphalt Layer } & 10 \\ \text { Asphalt Performance and Constructability } & 12 \\ \text { Review of Case Studies } & 12 \\ \text { Ballasted Railway Tracks with Asphalt } & 12 \\ \text { Ballastless Railway Track with Asphalt } & 13 \\ \text { Railway Tracks with Asphalt Mortar } & 14 \\ \text { Railway wath Modified Asphalt Mixtures } & 14 \\ \text { Asphalt Application in Urban Railway Tracks } & 15 \\ \text { Summary and Conclusions } & 15 \\ & 16\end{array}$

\section{Introduction}

In traditional railway systems, the ballast and sub-ballast layers are considered the main elements of the track for providing the strength required to support the track structure and protect the subgrade. Recent efforts include adding or replacing some of these layers with a concrete or asphalt layer. Concrete, which is mostly used in ballastless tracks, has been studied and developed extensively; however, the use of an asphalt layer needs more focus. During this literature review, the authors noticed that, while asphalt is among the common materials used in railway construction in many countries, a review of its use has not been gathered in a single paper. It is necessary to collect the available documents and research results in a comprehensive literature review and highlight the important findings of these investigations.

The application of bitumen as a pavement material dates back to the 1800 s when a sheet of asphalt layer was placed under a concrete base. Until the 1930s, the structural design and construction of pavements were based only on experience. However, after this date, early efforts to review the structural design of flexible pavements began [1]. The first applications of asphalt as a track bed date back to the 1960s and 1970s. Despite the rise in demand for slab track construction, the use of asphalt in railways did not grow as extensively as concrete. However, considering the fact that the lifetime of asphalt pavement can be extended to over 50 years [2], the total cost for its use could be less than a traditional ballasted track.

Since the 1970s, different applications of asphalt have been introduced and used in various places. In the United States, asphalt application in railways started in the early 1980s. Early applications mainly aimed at improving the strength of the track structure, specifically during renovation projects on existing lines. In general, the designs included adding a $15 \mathrm{~cm}$ layer of hot mix asphalt concrete between the ballast and the subgrade. Based on the literature, almost the same design application and configuration are still being used today [3]. Efforts are in place to design better mixes for all sorts of pavements, including highways, airfields, and railway layers, as well as improving construction techniques and production methods [4].

Many other countries have also been using asphalt products in railway structures. For instance, Japan, Spain, and Italy are among the countries that have successfully applied asphalt in their track systems [5]. In Germany, a method called Getrac, which is a system with an asphalt base layer, was approved as a construction type of ballastless track system for high speeds. Studies indicated that the system has benefits similar to other ballastless types while being fast and easy for construction. Asphaltic material has the advantage of 
higher flexibility compared to concrete, which makes it an ideal material to design and build a flexible system with a good bearing capacity for high-speed lines [6].

Table 1 presents the estimated lengths of railway tracks in several countries with different types of bituminous layers. The asphalt layer thicknesses vary for ballasted and ballastless systems; the overall thickness that is the most common in each country is presented.

Table 1. Lengths and thicknesses of railway tracks with bituminous layers in various countries.

\begin{tabular}{|c|c|c|c|c|c|c|c|c|}
\hline Country & Germany [7] & Italy [8] & France [9] & Morocco [9] & Spain [10] & China [11] & Japan [11] & USA [12] \\
\hline Length $(\mathrm{km})$ & 82 & 1200 & 300 & 200 & 300 & 2860 & 2200 & 322 \\
\hline $\begin{array}{l}\text { Asphalt/asphalt } \\
\text { mortar thickness } \\
\text { (cm) [13] }\end{array}$ & $20-30$ & 12 & 14 & 14 & $12-14$ & $3-5$ & 5 & $12-30$ \\
\hline
\end{tabular}

It is important to mention that, in the beginning, there were several problems involved with asphalt construction technology, especially fixing the track panel on a material with viscous behavior. This led to the introduction of different sleeper types and fastening systems. Through new developments in paving machinery and construction technology, it was possible to easily lay asphaltic layers, and at the same time, more precisely, which could satisfy the required installation tolerances $[13,14]$.

In terms of high-speed railway construction methods, the asphaltic track system is now one of the accepted standard systems in the German railway [15]. Compared to hydraulically bonded base layers (cement-stabilized or concrete materials), they can be loaded shortly after the end of compaction. This great advantage of asphalt makes it a favorable material for bearing capacity improvements in the upgrading of existing tracks for higher speeds, or the rehabilitation of existing high-speed ballasted tracks. To satisfy the stiffness and dynamic requirements of the load-bearing system, hot mix asphalt has been shown to be appropriate material. It is necessary to mention that in order to satisfy the lifecycle of the asphalt layer, fatigue damage and settlement are among the main aspects of the design criteria for this layer. Both of these aspects are related to the number of train passes. In this regard, Sociéte nationale des chemins de fer français (SNCF) recommends the following mechanical properties for the asphalt layer under a high-speed railway track [5]:

- $\quad$ stiffness modulus $\geq 11,000 \mathrm{MPa}$ (at $15^{\circ} \mathrm{C}$ and $10 \mathrm{~Hz}$ )

- fatigue $\geq 100$ microstrain.

The European Union's strategy for after 2030 is to build maintenance-free tracks in tunnels and other appropriate places [16], which means that there will be opportunities for asphalt and other bituminous materials as alternatives for concrete and cemented products in ballastless track systems. In addition to the European Union, investigators in Australia have been working on new methods for the construction of a high-speed railway with asphalt or asphaltic mortar [17].

The main applications of bituminous materials in a railway track bed include an underlayment between the ballast and sub-ballast layers, a replacement for the sub-ballast, a layer between the concrete slab or sleeper panels and the subgrade, a structural layer of an urban railway, a bituminous mortar layer between the concrete slab and the subgrade, a waterproofing layer, and a bearing capacity layer during the upgrade of existing lines for higher speeds. Considering the inherent characteristics of hot mix asphalt, and asphaltic materials over concrete and granular material in general, they have a high potential of being applied in existing railway tracks or as an element in the design of new railway lines. The next sections will cover various applications of asphalt and bituminous materials under railway tracks, along with technical recommendations, as well as the results of case studies on asphalt-based track systems. 


\section{Asphalt Pavement Applications in Railway Track Support Systems}

Various asphalt types and bituminous products have been introduced and used in railway construction. These include the applications of hot mix asphalt (HMA), warm mix asphalt (WMA), mastic asphalt, and asphalt mortar, with various types of bitumen, from normal bitumen and emulsion bitumen up to rubber and polymer-modified ones. The main reason behind most of these applications is to decrease the level of stress and strain transferred to the subgrade. Additional studies have looked at the waterproofing properties of asphaltic materials, which is also a form of protection of the subgrade.

In general, asphalt applications under railway tracks can be divided into three major categories: the first uses an asphalt mixture with a ballasted track, the second uses asphalt directly under railway tracks, and the third uses asphalt mortar.

\subsection{Asphalt in Ballasted Railway Tracks}

One of the main applications of asphalt mixtures is with a ballasted track. Figure 1 shows a schematic of a ballasted railway track with asphalt pavement as a supporting component. This method, which is common in the United States, is called "asphalt underlayment," and is composed of a layer of asphalt that is used instead of sub-ballast, or between the sub-ballast and ballast layers. In this system, the asphalt layer generally extends around $30 \mathrm{~cm}$ beyond the ends of the crossties on both sides.

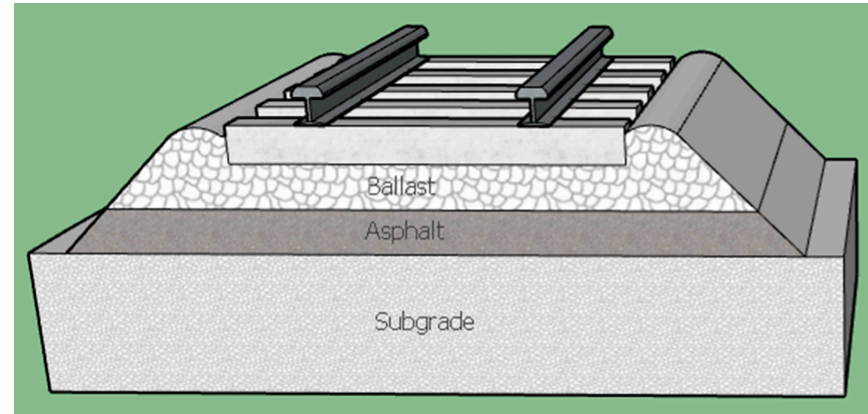

(a)

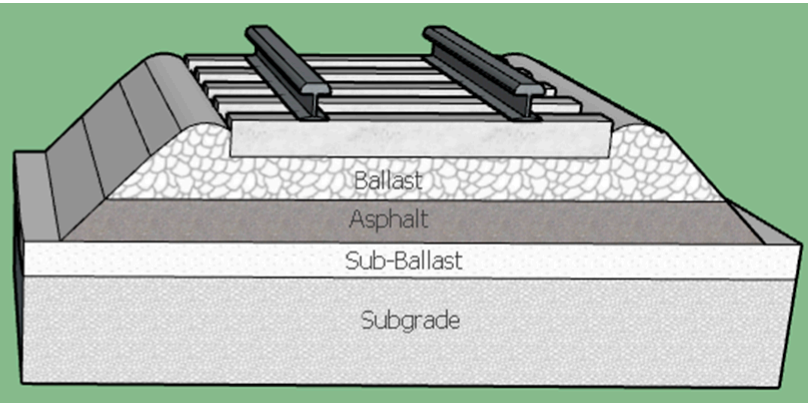

(b)

Figure 1. Schematic of combinations of asphalt layers in a ballasted track bed: (a) asphalt as a sub-ballast and (b) asphalt between the ballast and the sub-ballast.

The benefits of asphalt underlayment are higher track stiffness and bearing capacity, improved track geometrical stability, decreased vertical track deformation, waterproofing, enhanced durability, and reduced vibration [13]. Asphalt underlayment is recommended for at-grade rail crossings in order to minimize the track and road settlement in the crossing area over time [18]. Caltrain in San Francisco and Metrolink in Los Angeles were among the first urban railways to utilize a layer of asphalt with $20 \mathrm{~cm}$ and $15 \mathrm{~cm}$ of thickness under crossovers and crossings, respectively. Additionally, most new crossovers and turnouts on both lines are built over an asphalt layer [19]. The thickness of the ballast-covering layer has been shown to have a noticeable influence on the amount of maximum stress and strain produced at the bottom of the asphalt layer. The component properties of a typical railway track with asphalt underlayment used in the United States are presented in Table $2[20,21]$.

Table 2. Properties of a typical track with asphalt underlayment used in the USA [20,21].

\begin{tabular}{|c|c|c|c|c|}
\hline Layer & Thickness (cm) & Minimum Modulus (MPa) & Poisson's Ratio & Unit Weight $\left(\mathrm{kg} / \mathrm{m}^{3}\right)$ \\
\hline Ballast & $20-30$ & 50 & 0.35 & 1800 \\
\hline Asphalt & $15-30$ & 4200 & 0.45 & 2400 \\
\hline Sub-ballast & 10 & 25 & 0.35 & 1800 \\
\hline Subgrade & - & 85 & 0.4 & 2200 \\
\hline
\end{tabular}




\subsection{Asphalt in Ballastless Tracks}

The second category uses asphalt in ballastless tracks. In this method, asphalt is placed directly under the sleepers (crossties) or a concrete slab. This method acts similarly to a slab track. European countries first introduced this method specifically for constructing high-speed railways and urban transit lines. Figure 2 shows a schematic structure of a ballastless railway track with an asphalt layer.

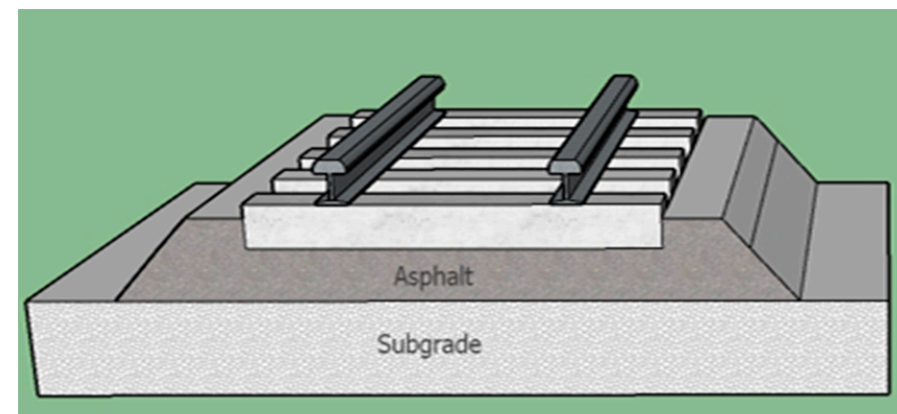

(a)

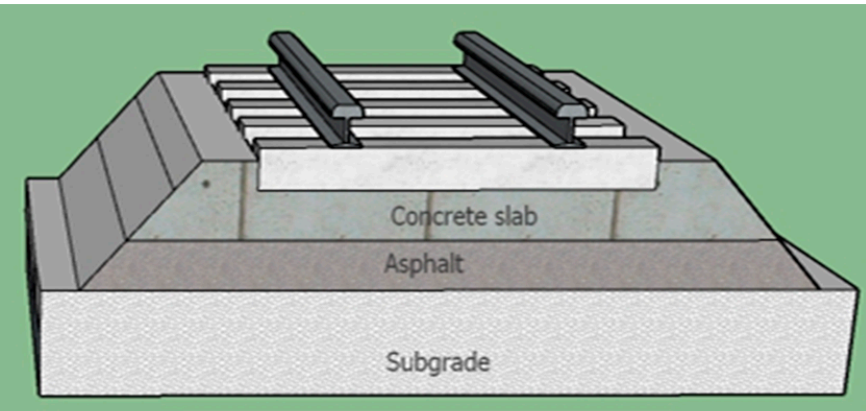

(b)

Figure 2. Schematic of combinations of ballastless layers in a track bed: (a) asphalt slab track and (b) asphalt between concrete slab and subgrade.

In the United States, asphalt is generally used under a concrete slab track. It is limited to lines with heavy freight traffic and for maintenance purposes. For the Long Island Station (LIRR), constructed in the 1980s, a layer of 10 to $15 \mathrm{~cm}$ of asphalt-treated sub-base was laid over a compacted subgrade to support 30 to $35 \mathrm{~cm}$ concrete slab track panels. It is notable that the slab track performance has not diminished, despite having been in service for a long time [22,23]. European countries have a higher tendency to use asphalt for ballastless tracks. Table 3 presents the specifications of various ballastless systems that include an asphalt base used on European railways.

Table 3. Specifications of asphalt bases in ballastless systems [24].

\begin{tabular}{cccc}
\hline Method & Asphalt Thickness (mm) & Superstructure Overall Thickness (mm) & Weight (ton/m) \\
\hline ATD & 300 & 1021 & 2.7 \\
SATO & 300 & 909 & 2.2 \\
FFYS & 300 & 909 & 2.2 \\
Getrac & 300 & 1021 & 2.7 \\
Walter & 300 & 929 & 2.3 \\
\hline
\end{tabular}

ATD: asphalt track bed directly laid on the sleeper, SATO, FFYS.

An ATD (asphalt track bed directly laid on the sleeper) system [24] includes an asphalt layer over a cement-stabilized sub-base, and the sleepers sit on top of this asphalt layer. Studiengesellschaft AsphalT Oberbra (SATO) and Feste Fahrbahn Y-Sleeper (FFYS) systems include Y-shape sleepers anchored into the asphalt layers under them. For the Walter method, monoblock sleepers are anchored to the asphalt layer [2] Getrac, which is the name of a ballastless slab track system developed in Germany, includes two sub-systems: Getrac A1 and Getrac A3. The main difference between them is related to the sleeper width. Getrac sleepers are quite heavy and have an anchor block to maintain the lateral stability of the system. The precision degree for asphalt base slab tracks is $\pm 2 \mathrm{~mm}$ in slab height [25-27]. Figure 3 demonstrates two sections of a ballastless Getrac track system. It is important to mention that, in some sections, in order to provide lateral resistance, a layer of ballast is added at the end of the sleepers, on the track shoulders. The ballast in these sections is placed over the track shoulders after constructing the railway slab track. 


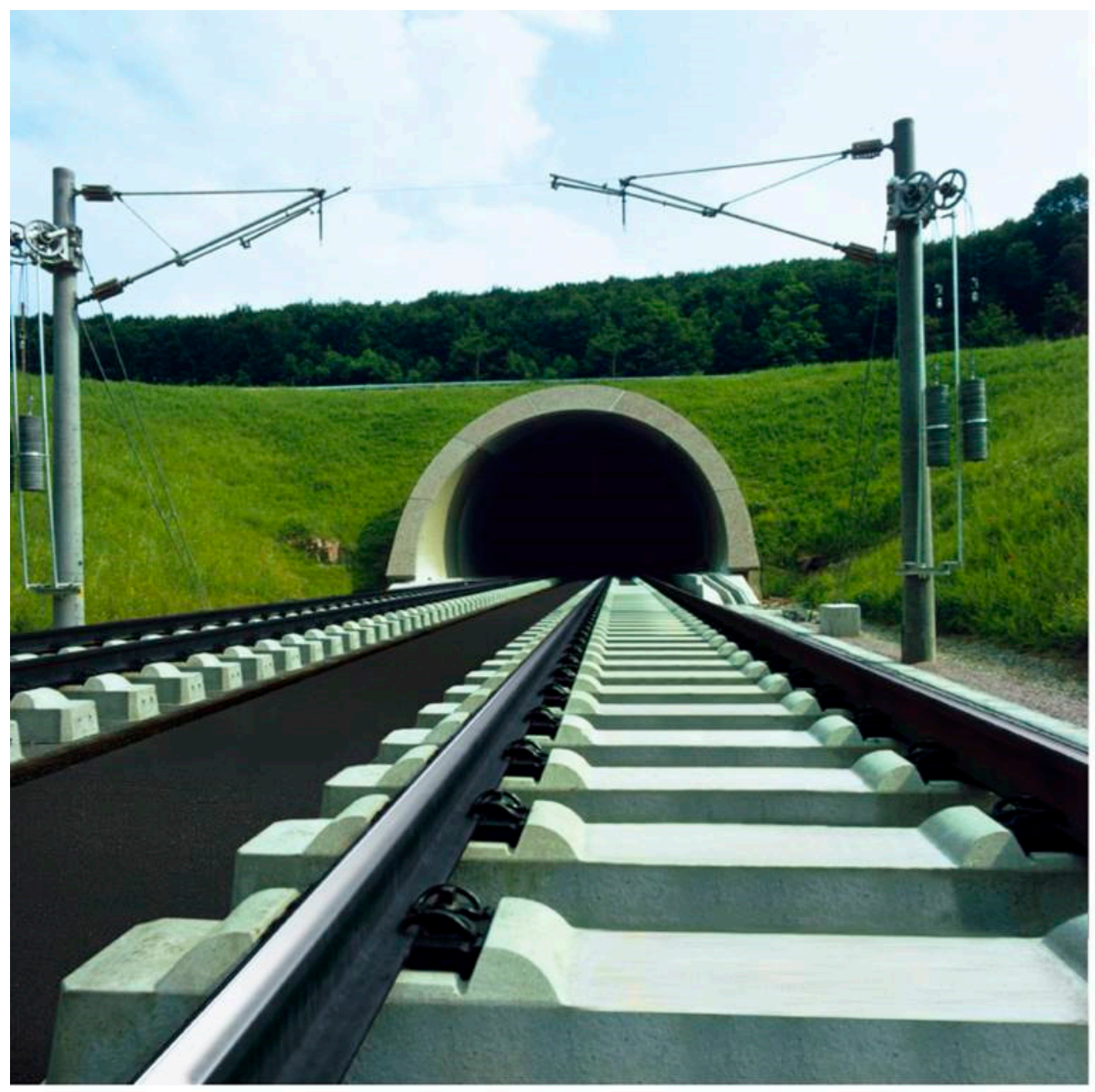

Figure 3. Getrac ballastless system with an asphalt layer (with permission from RAIL.ONE) [27].

\subsection{Asphalt Mortar in Ballastless Track}

In Japan, China, and Italy, to protect the subgrade, high-speed railway tracks are constructed over a layer of 5 to $8 \mathrm{~cm}$ of asphalt mortar. The design method used in Japan includes a prefabricated concrete slab over a bitumen-cement mortar [28,29]. In this method, the bitumen-cement mortar is one of the key components of the track structure. The asphalt layer transfers the load and distributes it uniformly on the subgrade. It also creates a waterproof surface, which keeps the subgrade moisture content constant. In addition, a higher mortar stiffness leads to a slight decrease in concrete slab displacement based on a dynamic analysis of the slab track behavior, although this influence could be neglected [30]. A study on a Chinese high-speed railway suggested a design with a thicker slab, lower rail fastening stiffness, and higher mortar stiffness to decrease the slab bending stresses [31]. Chinese high-speed railway designers consider mortar as a semi-rigid composite, which is injected between the track slab and the concrete bed. Mortar's mechanical properties, elastic modulus, and durability are dominant factors in determining the safety and service life of a high-speed railway [32]. It is important to mention that extreme climate has a significant influence on mortar's performance [33]. Figure 4 presents the bituminous mortar (bitumen-cement mortar) layer under a slab track. 


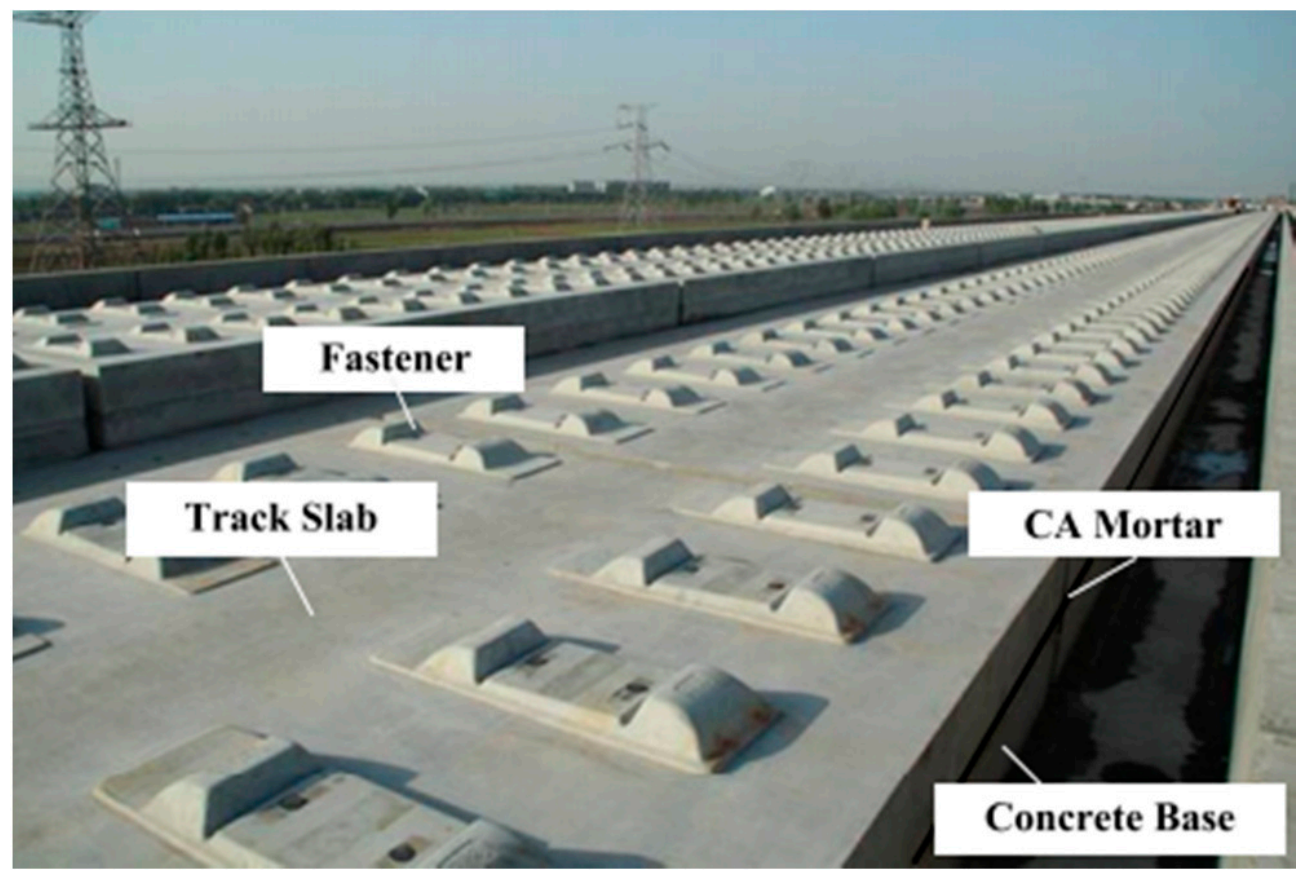

Figure 4. Cement Asphalt (CA) mortar under a slab track (with permission from American Society of Civil Engineers (ASCE)) [33].

\section{Recommendations on the Mix Design of Asphalt for Railway Tracks}

An important concern for the use of asphalt on a railway track is the mix design issue. Looking at the literature, different agencies and researchers have used various volumetric properties, aggregate types, and gradations. The following two sections present the various volumetric properties of asphalt mixtures and aggregate gradation.

\subsection{Volumetric Properties}

In order to produce asphalt, European countries have used their own national procedures, while the USA and many other countries have relied on the Marshall mix design and properties. Despite the fact that the Marshall design is a relatively old method, it has been proven to be appropriate for both the underlayment and overlayment methods. Recent studies have been based on applying Superpave recommendations for designing asphalt mixtures for railways. The specifications of the American Society for Testing and Materials (ASTM) D-3515 are used to produce asphalt mixtures for railroad structures in the USA [20]. A typical mixture design based on the Marshall method is presented in Table 4.

Table 4. Marshall mix design acceptance rates [34].

\begin{tabular}{|c|c|c|c|c|c|c|}
\hline \multirow[t]{2}{*}{ Mix Criteria } & \multicolumn{2}{|c|}{$\begin{array}{c}\text { Light Traffic } \\
\text { (<104 ESALs) }\end{array}$} & \multicolumn{2}{|c|}{$\begin{array}{l}\text { Medium Traffic } \\
\text { (104-106 ESALs) }\end{array}$} & \multicolumn{2}{|c|}{$\begin{array}{l}\text { Heavy Traffic } \\
\text { (>106 ESALs) }\end{array}$} \\
\hline & Min. & Max. & Min. & Max. & Min. & Max. \\
\hline Compaction (blows per each side) & \multicolumn{2}{|c|}{35} & \multicolumn{2}{|c|}{50} & \multicolumn{2}{|c|}{75} \\
\hline Minimum stability (minimum) & \multicolumn{2}{|c|}{$2224 \mathrm{~N}$} & \multicolumn{2}{|c|}{$3336 \mathrm{~N}$} & \multicolumn{2}{|c|}{$6672 \mathrm{~N}$} \\
\hline Flow $(0.25 \mathrm{~mm})$ & 8 & 20 & 8 & 18 & 8 & 16 \\
\hline Air voids $(\%)$ & 3 & 5 & 3 & 5 & 3 & 5 \\
\hline
\end{tabular}

ESALs: equivalent single axle loads.

ESALs are the equivalent single axle loads, with the most common equivalent load in the USA being 18,000 $\mathrm{lb}(80 \mathrm{kN})$. In the Marshall mix design method, the compaction (blow number) is generally 35,50 , or 75 strikes on each side of the cylindrical sample; stability is the maximum load capacity of the specimen; flow refers to the specimen's 
deformation, which is measured in $0.25 \mathrm{~mm}$; air voids are the total volume of air voids in the compacted specimen [34].

The recommendations of this table were prepared based on highway loading criteria. For railway applications, it is crucial to optimize the mixture design in order to achieve a balance between the resistance to permanent deformation and fatigue cracking [35]. The authors could not find mix design recommendations for all European countries, but as an example, in an investigation carried out in Italy, asphalt samples were made based on the Italian Standard in the experimental work [36]. Table 5 presents some of these specifications gathered from different studies. As indicated in this table, most studies have used methods similar to the Marshall mix method to design their asphalt mixtures. It has to be added that the reason for some cells being empty in Tables 5 and 6 is because the authors did not find the data relevant to these parameters in the given references. One reason for this could that many countries have developed their own standards, where these national standards are usually in languages other than English. For instance, in France, the SNCF has used the French asphalt type GB4 in developing asphalt layers under high-speed railways, in which the asphalt is compacted with a gyratory base method [37].

Table 5. Recommended properties of asphalt for railways.

\begin{tabular}{ccccccccc}
\hline Study Reference & $\begin{array}{c}\text { Compaction } \\
\text { (Blow Number) }\end{array}$ & $\begin{array}{c}\text { Stability } \\
\mathbf{( N )}\end{array}$ & Flow & $\begin{array}{c}\mathbf{V}_{\mathbf{a}} \\
\mathbf{( \% )}\end{array}$ & $\begin{array}{c}\text { VFA } \\
\mathbf{( \% )}\end{array}$ & $\begin{array}{c}\text { VMA } \\
\mathbf{( \% )}\end{array}$ & $\begin{array}{c}\text { Binder } \\
\text { Content } \mathbf{( \% )}\end{array}$ & $\begin{array}{c}\text { Density } \\
\left(\mathbf{k g} / \mathbf{m}^{3}\right)\end{array}$ \\
\hline USA [38] & 50 & 3375 & $3.8-6.4$ & $1-3$ & $80-90$ & & $6.5-7.4$ & 2240 \\
Italy [39] & $102-291$ & 10,000 & - & $2-4$ & $75.4-82.4$ & $12.4-18.6$ & $4-7$ & 2500 \\
Korea [35] & - & - & - & 3 & - & - & 4.4 & 2496 \\
Iran [40] & 50 & 9400 & 2.5 & 8.5 & - & - & - & 2216 \\
Korea [41] & - & $>4900$ & $20-40$ & 3 & $70-80$ & $>13$ & $5.2-5.5$ & 2353 \\
Spain [42] & $50-75$ & 11,850 & 3.9 & 2.8 & - & - & 4.25 & 2650 \\
France [43] & - & - & - & $3-4$ & - & - & 4.8 & - \\
China [44] & - & 8000 & - & $1-3$ & $89-91$ & $12.6-16$ & $4.5-5.8$ & 2525 \\
\hline
\end{tabular}

$\mathrm{V}_{\mathrm{a}}$ : air void ratio, VFA: voids filled with asphalt, VMA: voids in mineral aggregates.

Moreover, the authors did not find any specific analysis within these documents about the comparison between different mix designs or aggregate gradations. However, the authors believe it is important for those who read this article to know the mix design properties and gradations being used by some studies. It may help some researchers to define a project in order to discover the influence of these parameters on asphalt under railways.

In this table, $V_{a}$ is the air void ratio, VFA represents the voids filled with asphalt, and VMA represents the voids in mineral aggregates. Some of these specifications are based on European standards and specifications; to design asphalt mixtures for tracks inside tunnels, manufactured asphalt must be easy to handle. Using warm mix asphalt allows for decreasing the compaction temperature by around $30^{\circ} \mathrm{C}$ compared to conventional HMA [45]. In order to provide a waterproof coating, especially for high-speed railway tracks, mastic asphalt is a good and suggested option, especially in cold areas, to minimize the damage caused by freeze and thaw [46].

\subsection{Aggregate Gradation}

The aggregate gradation that has been used to produce asphalt mixtures for some case studies are presented in Table 6. One study recommended keeping the aggregate's maximum size under $25 \mathrm{~mm}$ and mixing it with approximately $5.8 \%$ of binder [47]. Other than that, the authors did not find any technical properties or differences that were specifically related to a recommended gradation for these types of asphalt mixes. In most studies, the researchers used the gradation that is typically used in highways. Moreover, Spanish railway authorities provided the following recommendations to cover the mechanical characteristics of the aggregate for asphalt layer under a railway [5]. 
- $\quad$ sand equivalent $>50$;

- $\quad$ angular particles $>90 \%$;

- $\quad$ Los Angeles Abrasion Test $>25 \%$;

- Elongation and Flakiness Indexes $<25$;

- filler $>50 \%$.

Table 6. Aggregate gradation for asphalt mixtures on railways.

\begin{tabular}{ccccccc}
\hline \multirow{2}{*}{ Sieve Size/Number } & \multicolumn{7}{c}{ Passing Percentage (\%) } \\
\cline { 2 - 6 } & {$[5]$} & {$[23]$} & {$[48]$} & {$[49]$} & {$[35]$} & {$[42]$} \\
\hline $37.5 \mathrm{~mm}$ & & & & 100 & 100 \\
$31.5 \mathrm{~mm}$ & 100 & 100 & 100 & - & $90-100$ \\
$25.4 \mathrm{~mm}$ & - & $90-100$ & - & $90-100$ & - & - \\
$22.4 \mathrm{~mm}$ & $90-100$ & - & 92.39 & - & & $78-95$ \\
$19 \mathrm{~mm}$ & - & - & - & $78-95$ & 100 & $67-87$ \\
$16 \mathrm{~mm}$ & $70-88$ & - & 77.18 & $67-87$ & - & $56-60$ \\
$12.5 \mathrm{~mm}$ & - & $70-90$ & - & $56-80$ & 89.9 & - \\
$11.2 \mathrm{~mm}$ & - & - & 63.28 & - & - & $42-68$ \\
$9.5 \mathrm{~mm}$ & - & - & - & $42-68$ & 75.5 & - \\
$8.0 \mathrm{~mm}$ & $50-66$ & - & 54.96 & - & - & - \\
$5.66 \mathrm{~mm}$ & - & - & 47.2 & - & - & $29-57$ \\
$4.75 \mathrm{~mm}$ (no. 4) & - & $40-65$ & 38.4 & $29-57$ & 55.7 & $19-45$ \\
$2.0 \mathrm{~mm}$ (no. 10) & $24-38$ & $25-45$ & 27.75 & $19-45$ & 39.2 & $14-34$ \\
$1.18 \mathrm{~mm}$ (no. 16) & - & - & - & $14-34$ & - & - \\
$1.0 \mathrm{~mm}$ (no. 18) & - & - & 20.69 & - & - & $10-25$ \\
$0.595 \mathrm{~mm}$ (no. 30) & $11-21$ & - & - & $10-25$ & 18.8 & $5-17$ \\
$0.42 \mathrm{~mm}$ (no. 40) & - & $10-26$ & 15.72 & $5-17$ & - & - \\
$0.177 \mathrm{~mm}$ (no. 80) & $8-6$ & $6-18$ & 10.41 & $3-10$ & - & $3-10$ \\
$0.149 \mathrm{~mm}$ (no. 100) & - & - & - & - & 9.4 & $1-7$ \\
$0.075 \mathrm{~mm}$ (no. 200) & - & $3-8$ & - & - & 6.5 & - \\
$0.063 \mathrm{~mm}$ (no. 230) & $4.5-8$ & - & 6.75 & - & - & \\
\hline & & & & & & \\
\hline
\end{tabular}

\section{Structural Properties of Asphalt Layer}

In terms of the physical properties of the asphalt layer, the main factors are the subgrade bearing capacity and the track settlement restriction. Traditionally, the total track settlement is superposed on the settlement in each layer [50].

Track settlement is relevant to the subgrade modulus, where the subgrade modulus is related to each layer's thickness [51]. Hwang et al. [52]. suggested the following equation based on a nonlinear elastic multilayer system under the railway to calculate the dynamic modulus of a hot mix asphalt layer. This equation is based on the Asphalt Institute's model:

$$
\mathrm{E}=10^{5}+10^{\beta_{1}}
$$

where $\beta_{1}$ is a constant and is related to four other constants, which are $\beta_{2}, \beta_{3}, \beta_{4}$, and $\beta_{5}$.

In order to calculate $\beta_{1}$, the above four constants should be calculated. Then $\beta_{1}$ will be plugged in into Equation (1) to determine the dynamic modulus of hot mix asphalt.

The following equations present how to calculate $\beta_{1}, \beta_{2}, \beta_{3}, \beta_{4}$, and $\beta_{5}$ :

$$
\begin{gathered}
\beta_{1}=\beta_{3}+0.000005 \beta_{2}-0.00189 \beta_{2} f^{-1.1}, \\
\beta_{2}=\beta_{4}^{0.5} \mathrm{~T}^{\beta_{5}} \\
\beta_{3}=0.553833+0.028829 \mathrm{P}_{200} f^{-0.1703}-0.03476 \mathrm{~V}_{\mathrm{V}}+0.070377 \eta+0.931757 f^{0.0277}, \\
\beta_{4}=0.483 \mathrm{~V}_{\mathrm{b}} \\
\beta_{5}=1.3+0.49825 \log f .
\end{gathered}
$$

The parameters presented in the above equations are as follows: 
$E$ is the dynamic modulus of the hot mix asphalt in pounds per square inch; $\beta_{1}, \beta_{2}$, $\beta_{3}, \beta_{4}$, and $\beta_{5}$ are temporary constants; $E$ is the dynamic modulus of elasticity (psi) for the HMA layer; $\mathrm{T}$ is the temperature $\left({ }^{\circ} \mathrm{F}\right) ; \mathrm{P}_{200}$ is the percent of aggregate passing sieve no. $200 ; f$ is the load frequency; $V_{\mathrm{v}}$ is the air voids percentage; $\mathrm{V}_{\mathrm{b}}$ is the binder content; $\eta$ is the viscosity of the bitumen.

It is also possible to perform the dynamic stiffness tests on laboratory-made samples from the designed mix for the project at different temperatures and loading frequencies. The results will be used to construct the stiffness master curve of the asphalt, and then it is possible to determine the dynamic modulus at any desired temperature and loading frequency. In order to make the calculations easier, the developers of the Kentrack computer model have recommended using an empirical model, as suggested by the Mechanistic Empirical Pavement Design Guide (MPEDG), to calculate the dynamic modulus for hot mix asphalt. It is accepted that an asphalt layer is almost elastic at temperatures under $20^{\circ} \mathrm{C}$, with a dynamic modulus of elasticity between 5000 and $10,000 \mathrm{~N} / \mathrm{mm}^{2}$. However, when the asphalt layer's temperature exceeds $20^{\circ} \mathrm{C}$, plastic deformation is accumulated around the load contact area, which needs to be addressed and limited.

Based on the dynamic modulus of the asphalt and subgrade, the following equations, which were proposed by the Asphalt Institute [53], can be used to calculate the amount of allowable repetitive loading in an asphalt layer and over the subgrade:

$$
\begin{gathered}
\mathrm{N}_{\mathrm{a}}=0.0795 \varepsilon_{\mathrm{t}}^{-3.291} \mathrm{E}_{\mathrm{a}}^{-0.854,} \\
\mathrm{~N}_{\mathrm{d}}=4.837 \times 10^{-5} \sigma_{\mathrm{c}}^{-3.734} \mathrm{E}_{\mathrm{s}}^{3.853,}
\end{gathered}
$$

where:

$\mathrm{N}_{\mathrm{a}}$ is the allowable number of repetitive loads in the asphalt layer;

$\varepsilon_{t}$ is the horizontal tensile strain under the asphalt layer;

$\mathrm{E}_{\mathrm{a}}$ is the asphalt dynamic modulus (psi);

$\mathrm{N}_{\mathrm{d}}$ is the allowable number of repetitive loads in the subgrade layer;

$\sigma_{\mathrm{c}}$ is the compressive stress on top of the subgrade layer;

$\mathrm{E}_{\mathrm{s}}$ is the modulus of subgrade (psi).

Besides the asphalt dynamic modulus, another important parameter that needs to be calculated is the track modulus or stiffness. The traditional equation for calculating the track modulus is as follows [53,54]:

$$
\mathrm{u}=\frac{1}{4} \sqrt[3]{\frac{\mathrm{P}^{4}}{\mathrm{EIW}_{\mathrm{m}}^{4}}}
$$

where:

$\mathrm{u}$ is the subgrade elasticity (lb/in/in);

$\mathrm{P}$ is the amount of wheel load (lb);

$\mathrm{E}$ is the rail modulus of elasticity (psi);

I is the rail moment of inertia (in $\left.{ }^{4}\right)$;

$\mathrm{w}_{\mathrm{m}}$ is the deflection under the wheel (in).

This equation is common, especially in the USA, because it is easy to use, but the problem is that a special test setup is required for applying the load and measuring the deformation. To solve this problem, investigators have suggested simpler methods, such as the Plate Load Test (PLT), or have tried to use the results of the California Bearing Capacity (CBR) Test or the modulus of resilience $\left(\mathrm{M}_{R}\right)$ in order to calculate the subgrade modulus of elasticity $[55,56]$. The amount of pressure produced over the asphalt layer under the sleeper is less than $0.3 \mathrm{~N} / \mathrm{mm}^{2}$ for a typical passenger train, while it is between 0.7 and $0.9 \mathrm{~N} / \mathrm{mm}^{2}$ for heavy trucks on highways [57,58].

The typical thickness for a bituminous layer on an Italian high-speed railway is between 12 to $14 \mathrm{~cm}$, which lays over a densely compacted aggregate layer [59]. In this 
regard, rubber-modified asphalt can enhance the energy absorption properties of the subballast layer for high-speed conditions [60]. However, in terms of energy absorption, both modified and non-modified bituminous sub-ballasts improve the track properties. In addition, careful consideration should be given to ensure that the track geometry and bearing capacity restrictions are suitable for high-speed railways [61]. In this regard, the asphalt layer should have the capability to decrease the magnitude of vertical stress to lower than $0.05 \mathrm{~N} / \mathrm{mm}^{2}$ over the subgrade layer [62].

To determine the critical responses (vertical stress on the subgrade and horizontal strain under the asphalt layer), different computer programs can be used, from simple multilayer elastic models, up to more complicated ones that are also capable of considering the railway's superstructure. Kentrack is a program that was developed to analyze railroad tracks, including the ones with an asphalt underlayment [63,64]. It is also possible to perform stiffness and fatigue tests directly on laboratory-produced asphalt samples to determine the main inputs for the computer model, to determine the critical responses, and to predict the lifespan (like the mechanistic-empirical approach), instead of using the abovementioned equations. Stiffness tests can be performed at different temperatures and loading frequencies to be able to construct the stiffness master curve of the asphaltic material, as well as to consider the effect of train speeds, or the temperature changes on the stiffness of the asphaltic layer.

\section{Asphalt Performance and Constructability}

Considering that an asphalt layer does not require curing after being laid on the track bed, it is a suitable material for ballastless track applications, specifically when sleepers are laid directly on it. A survey on construction progress, in meters per day of construction, for various ballastless tracks showed Rheda 2000 has the highest performance because it is totally mechanized. Other than that, track systems with asphalt layers are the systems with high productivity compared to other concrete slab systems [24]. In the case of asphalt pavement, it cools down in two to three hours, reaching a minimum compressive pressure resistance of $12 \mathrm{~N} / \mathrm{mm}^{2}$, while it takes three to seven days for a concrete slab to reach the same amount. For asphalt, in the case of hot mixes, the main point is related to logistics and transporting the mix from the production facility to the laydown place. Recent developments in the area of mobile mixing plants have made this issue less critical.

In order to evaluate the performance of an asphalt layer, several $[65,66]$ performed a numerical analysis on an asphalt layer under a high-speed railway and concluded that the optimal location of the asphalt layer is under the ballast and over the subgrade, which will lead to a higher bearing capacity in the track bed. Moreover, in order to decrease construction costs, a specific asphalt mortar pouring method with a long pipe was recommended for a line located in a snowy region of Japan [67]. In terms of construction cost, a research study on Spain's high-speed railway track revealed that in many cases, the construction costs of tracks with a bituminous sub-ballast were similar to tracks with an all granular sub-ballast [68].

\section{Review of Case Studies}

This section focuses on a review of investigations performed on asphalt pavement and mortar under a railway track. Considering that researchers have shown interest in both traditional and modified asphalt, the findings for each are presented in one subsection. The last subsection also provides the results of investigations on asphalt concrete under a railway track.

\subsection{Ballasted Railway Tracks with Asphalt}

Studies have revealed a positive influence, as well as benefits, for using asphalt as a track layer. In an experimental study [20], sections of 10 to $30 \mathrm{~cm}$ of an asphalt layer were installed under various railway tracks. Based on the results, after seven years, the sections having asphalt underlayment required less geometrical realigning and re-ballasting 
compared to a ballasted track. In addition, the subgrade under the asphalt layer was found to remain uniform. On-site investigations of a trial railway section with Y-shape sleepers over two layers of asphalt pavement with a $15 \mathrm{~cm}$ thickness presented a higher lateral resistance and lower vibration rate, which means a longer track lifecycle [69].

Moreover, asphalt creates a waterproofing layer, with better separation between the ballast and subgrade layers, which helps to eliminate the negative impact of a mud pumping subgrade and ballast fouling [38]. A layer of thick hot mix asphalt increases the overall modulus of the track packet compared to a ballasted one. The higher track modulus leads to lower strain under an asphalt layer. Therefore, it is necessary to find and recommend an optimal thickness for an asphalt layer. In this regard, a theoretical analysis suggested an asphalt layer with a thickness of 12 to $14 \mathrm{~cm}$ to be a sufficient alternative for a $30 \mathrm{~cm}$ traditional sub-ballast layer [70].

A bituminous layer is an appropriate alternative to traditional granular materials and helps to improve track performance by decreasing the track settlement and enhancing the track bearing capacity [53], track stiffness [71-74], and stability and fatigue resistance [75-77], as well as reducing the track's vertical acceleration [78], and its overall thickness, especially in tunnels [79]. Furthermore, in a trial section under the Train à Grande Vitesse (TGV) high-speed railway, French experts were able to decrease the total thickness of the track by $21 \mathrm{~cm}$ by replacing a $35 \mathrm{~cm}$ base layer with a $14 \mathrm{~cm}$ asphalt layer between the ballast and formation layers. The asphalt modulus used in this section was over 11,000 MPa [3].

A transition zone, which is the section between a ballasted track and a slab track, or more specifically, the section on both sides of a concrete bridge slab in a ballasted track, is required to be designed and installed [80], One of the secondary applications of the asphalt is that it is an ideal material that can be applied in transition zones to restrict permanent settlement $[81,82]$, increase the track modulus, and overcome the stiffness differences [83]. between the ballast and bridge's or tunnel's concrete deck. A layer of $20 \mathrm{~cm}$ of asphalt underlayment with a length of over $60 \mathrm{~m}[84,85]$ is one recommended method [86] for a transition zone, while a $30 \mathrm{~cm}$ asphalt underlayment behaves similar to $20 \mathrm{~cm}$ of concrete layer over the subgrade. For instance, the design method used for renovating bridge approach sections by the CSX railroad (in the USA) included a $12.2 \mathrm{~m}$ long asphalt underlayment with a $15 \mathrm{~cm}$ thickness [87].

More recent long-term monitoring projects show asphalt's significant influence in distributing the load and reducing the amount of pressure on a track's bed [88], thereby decreasing its settlement [89]. Asphalt underlayment presents benefits for both high-speed and freight railway [90], as well as in cases of heavy-haul railways [91]. In contrast, a two-year experimental study on $105 \mathrm{~km}$ of a high-speed ballasted track with asphalt underlayment in France displayed a reduction in the acceleration level under the ballast layer, but no significant improvement in track settlement for a track with an asphalt underlayment in comparison to a track with conventional granular material. Based on this study, the asphalt underlayment section presented better drainage properties and embankment protection. Another point about using asphalt underlayment is that the ballast layer provides a kind of protection against severe temperature changes [92,93]. In addition, investigations are ongoing by French railway authorities to develop an asphaltic layer as an alternative for freight traffic, especially in tunnels, to increase the tunnel gauge by decreasing the overall thickness of the track [94].

Modifying the ballast with a bitumen emulsion is another method that some experts have suggested for enhancing ballast properties. Bitumen brings more cohesion into the mix, enhancing its shear resistance parameters, and consequently, improving its mechanical and response properties regarding cyclic loading. The ballast gradation, along with the emulsion's type and dosage, are among the important factors that have an influence on the outcome [95]. Bitumen emulsion also decreases permanent deformation, as well as the deformation rate in the ballast layer [89], along with particle degradation, by preventing particle movement and friction [96]. Emulsion increases a ballast's durability, especially for 
early applied cases [97]. An emulsion-modified ballast requires a different maintenance strategy because the modification can lead to a more sustainable ballast, and therefore, to an increase in the maintenance intervals $[98,99]$. This method of stabilizing the ballast particles was first introduced by a team of researchers at Heriot-Watt University in 2004 [100,101].

\subsection{Ballastless Railway Track with Asphalt}

In an analytical research study, the behavior of various railway substructures with three different HMA applications was investigated [21]. The three asphalt applications included: system 1-a concrete slab track, system 2-a concrete slab over an asphalt pavement, and system 3-adding a reinforced concrete layer between the asphalt layer and the concrete slab. The results demonstrated a similarity between the dynamic responses of the slab track (system 1) and the asphalt layer under reinforced concrete (system 3). Moreover, the asphalt layer improved the resilience performance of the track substructure, as well as the stress distribution. In addition, the various concepts of dynamic loading [102], and its influence on the behavior of the railway track over an asphalt slab bed was presented by some investigators [103]. 3D finite element model and laboratory tests were proposed by other investigators to analyze the dynamic behavior of the track bed [104,105]. It has to be mentioned that, despite having some differences, the in situ experiments usually validated the acceptance of the dynamic and numerical modeling [106,107]. Based on a finite element model, the use of an asphalt layer improves the sleeper support [108]. Dynamic modes were also used to analyze the influence of temperature on an asphalt layer in a slab track, as well as the waterproofing properties of the bituminous layer $[109,110]$. Several case studies and models in China have recommended self-compacted and mastic asphalt due to its effectiveness at enhancing the waterproofing properties of the asphalt layer [111,112].

A full-scale experiment on a Korean railway presented the benefits of using asphalt for railway systems. In this study, the optimal thickness for an asphalt layer was suggested to be $30 \mathrm{~cm}$ after applying static loading on track beds with three different thicknesses. The authors also discovered that the amount of transverse strain under the asphalt layer was less than 100 microstrain, which means that the asphalt layer had the capability to withstand the train's load [113]. Another experimental investigation by this team showed $3 \mathrm{~mm}$ of settlement for a track made of a $35 \mathrm{~cm}$ asphalt layer under cyclic loading [114]. Asphalt also increases the permanent deformation resistance of the track and remarkably improves the durability and service life of the track [115], while the roadbed pressure and strain underneath the asphalt layer remain in the acceptable range in the long-term [116].

\subsection{Railway Tracks with Modified Asphalt Mixtures}

The performance of asphalt pavement modified with various additives, such as rubber and polymer under the track bed, was considered in some studies. An investigation about using rubber-modified asphalt illustrated that dry asphalt rubber concrete improves the sub-ballast fatigue resistance $[117,118]$. In particular, it improves the track elasticity and its effectiveness in damping vibrations [119]. Furthermore, it has been discovered that asphalt modified with 10 to $20 \%$ rubber leads to an improvement in the shear modulus and damping ratio, though both factors are significantly related to temperature [120]. In addition, for asphalt modified with $20 \%$ rubber, the penetration resistance is higher compared to traditional, non-modified asphalt [121].

Polymer modified asphalt, on the other hand, increases the elastic recovery of the binder, as well as the viscosity and strength of the asphalt [122]. Moreover, in a comparison between the behaviors of Styrene-Butadiene-Styrene (SBS)-modified asphalt with rubbermodified asphalt under a railway [35], both presented higher elastic and viscoelastic behaviors under a uniaxial creep test, while the SBS-modified one, demonstrated a higher stiffness. With a 5.5\% optimum binder content, SBS-polymer-modified asphalt displayed the highest resistance to fatigue deterioration and rutting [41]. 


\subsection{Railway Tracks with Asphalt Mortar}

In an investigation on slab tracks used on a Chinese high-speed railway, the team proposed using reactive powder concrete materials to decrease the cracks at the slab, asphalt mortar, and roadbed [123]. Another study on asphalt mortar revealed that the flexural strength of mortar decreases with the increase of temperature [124]. Asphalt mortar is a sensitive material when exposed to temperature and constant pressure; it deteriorates more as the pressure and temperature increase [125]. Furthermore, in order to design asphalt mortar with a slab track, special consideration needs to be given to predict the mortar's deterioration and shock-absorbing properties of bitumen emulsion and fine aggregate admixture [126].

An increase in asphalt mortar thickness minimizes the amount of maximum tensile strain and the magnitude of track deformation under cyclic loading. The recommended thickness of asphalt mortar is between 10 and $50 \mathrm{~mm}$, with a modulus of elasticity between 7000 and $10,000 \mathrm{~N} / \mathrm{mm}^{2}$. Higher asphalt mortar stiffness leads to a reduction in slab track bending stresses, and consequently, track deformation [29]. Based on dynamic analysis models proposed by different researchers, for a moving wheel load, asphalt slab tracks create firm support for sleepers while decreasing the noise rate under dynamic loading [127-131]. One important factor when analyzing the asphalt mortar under the railway track is the temperature and its influence on the behavior of mortar. Higher temperatures lead to a decrease in the mortar's dynamic modulus [132]. In this regard, some experts have suggested more in-depth analyses to reveal the correlation between the mortar's dynamic properties and various temperatures [133]. Temperature and asphalt/cement volume ratio are two parameters having influence on the mortar's compressive strength [134]. Moreover, other researchers investigated the bonding between mortar and slab, and because this bond is generally not strong, some suggested adding polymer latex to improve the bonding strength of the mortar, as well as a quick-hardening admixture. In addition, improving the mortar strength provides reasonable support to the joints [135-139].

\section{Asphalt Application in Urban Railway Tracks}

Asphalt has also has been used extensively in the construction of urban railway tracks. The most well-known samples for this type of track are embedded track and tram system tracks. Typically, urban trains have lighter weights, and for an urban track, the axle load is less than for a regular railway. In these systems, asphalt is used for structural purposes or filling, as well as a combination of both. Figure 5 presents a schematic of a light rail with an asphalt track bed.

One method of using asphalt as a structural element in urban tram tracks is the Nikex (webless) system. This system, which includes three layers of asphalt under a concrete slab track, was used in the Netherlands in the early 1980s to build tram tracks [140]. The propagation of waves over the rail profile was a limiting factor behind why this system was not successful [141]. 


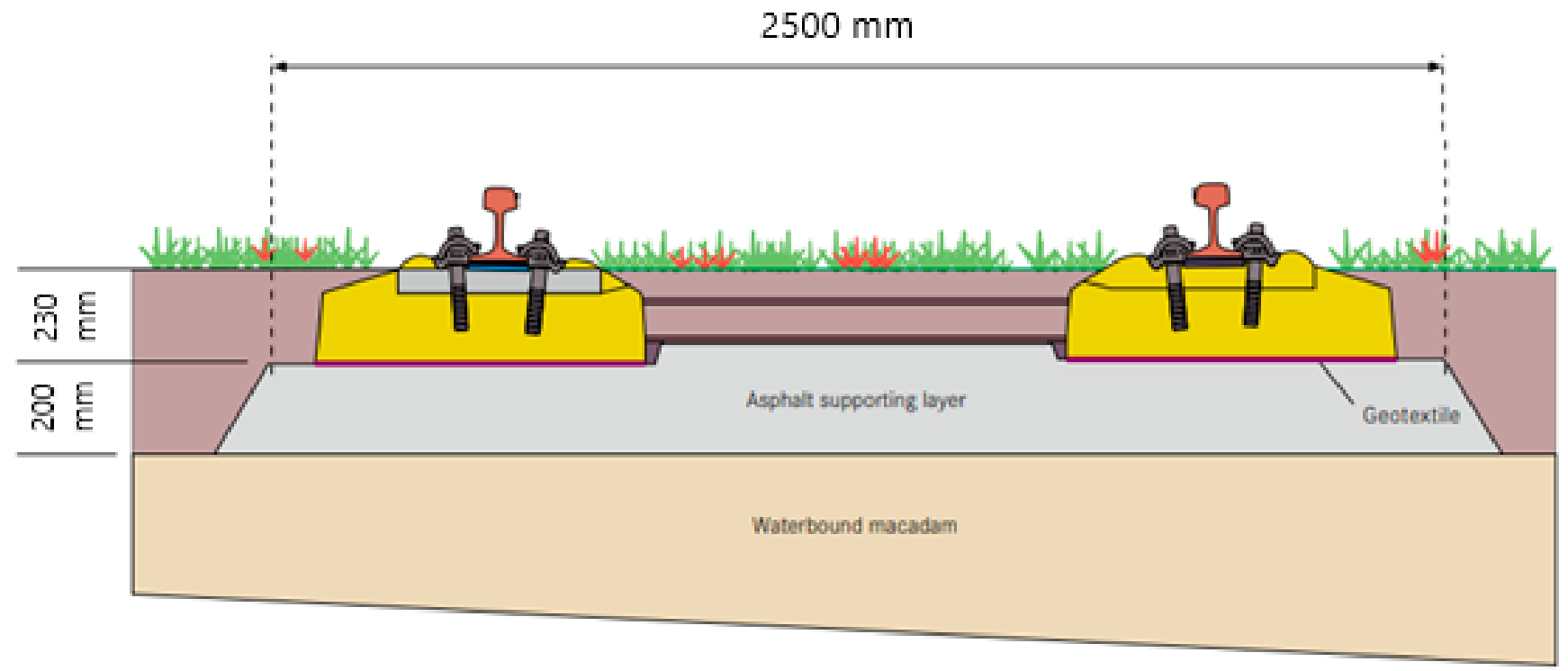

Figure 5. Schematic of a light rail with an asphalt track bed (With permission from RAIL.ONE) [142].

Another well-developed urban railway system is embedded rail. The type of asphalt used in an embedded track is different than regular asphalt. In this system, a $20 \mathrm{~cm}$ layer, which is called surface asphalt concrete (SAC), is laid over unbound crushed masonry to create a base for embedding the asphalt layer. The air void content in this type of asphalt is relatively high; in the range of 15 to $20 \%$, a kind of cement-based mortar mix is used to fill these voids. This type of asphalt is considered to have higher strength and stiffness, as well as better bearing capacity against settlement under heavy loading [143]. However, the properties of this type of asphalt are considerably related to temperature [144].

\section{Summary and Conclusions}

In this paper, different aspects of the application of asphaltic and bituminous materials under a railway track were investigated. Investigations about all types of asphalt applications under a railway track, including underlayment, overlayment, slab track, and asphalt mortar, as well as applying different modified asphalts, were reviewed. Table 7 presents a summary of various asphalt and bituminous materials that are common or have been studied in different countries.

Table 7. Various applications of asphalt and bituminous materials under railways.

\begin{tabular}{cccc}
\hline Country & Type & Common Thickness (cm) & Speed \\
\hline USA & Asphalt underlayment & $15-30$ & Regular \\
Germany & Slab track & $20-30$ & High speed \\
France & Asphalt underlayment & 14 & High speed \\
Italy & Slab track & 12 & High speed \\
Japan & Bitumenus mortar & 5 & High speed \\
China & Bituminous mortar & 5 & High speed \\
\hline
\end{tabular}

Moreover, the results of this investigation are summarized as follows:

1. The use of asphalt underlayment with a traditional ballasted track leads to an increase in the track stiffness and a decrease in its overall settlement. This is an important parameter that has a direct influence on track maintenance costs. Moreover, ballasted tracks with asphalt underlayment will have lower maintenance in comparison to those with a traditional granular sub-ballast.

2. The amount of stress and strain under a railway track with asphalt underlayment is mainly related to the layer thickness, but in general, replacing granular materials 
with asphalt pavement can decrease the overall height of the ballasted railway track. In tunnels, especially, this parameter is a dominant factor, which means a reduction in the overall tunnel height and cross-sectional area. Asphalt also has waterproofing properties, which protect the subgrade from moisture-related damage.

3. In addition, asphalt is a good alternative to a concrete slab when constructing ballastless railway tracks for high-speed and urban systems. It provides a good level of stiffness balance in the whole track system, which is crucial for its overall stability (acceptable level of settlement), and simultaneously, its response to the dynamic loads of high-speed trains. In France and Italy, specifications and standards have been established to cover the use of the asphalt slab track under high-speed railways. Countries like Spain and Austria have already used asphalt when constructing highspeed railways. In Germany, different methods, such as Gentrac and ATD, have been introduced, which are based on using asphalt as a bearing capacity layer for ballastless tracks. Moreover, thanks to the advances in construction machines, constructing a ballastless track with asphalt pavement is nowadays precise, and in most cases, faster than concrete slabs.

4. Other countries, such as Japan and China, are currently using asphalt mortar between the concrete slab and concrete bed as part of their design systems for slab tracks. In these countries, numerous studies have been performed on this system, which presents the positive influence of an asphalt mortar layer on a slab track.

5. Additionally, other studies on modified asphalt present the feasibility of using a modified bitumen binder and asphalt mixture in railway tracks. In this regard, both polymer and rubber-modified asphalts add significant benefits to the performance of track systems.

Author Contributions: K.J.: main and corresponding author; M.E.: technical editor; M.K. (Mehdi Kalantari): technical editor and data provider for German and European Railway; M.K. (Mehdi Khalili): technical editor for the asphalt section; M.K. (Moses Karakouzian): main technical editor. All authors have read and agreed to the published version of the manuscript.

Funding: The publication fees for this article were supported by the UNLV University Libraries Open Article Fund.

Conflicts of Interest: This article does not have any conflict of interest.

\section{References}

1. Pavement History. Available online: http://www.pavementinteractive.org/pavement-history/ (accessed on 29 December 2020).

2. Michas, G. Slab Track Systems for High-Speed Railways. Master's Thesis, Department of Transport Science, Royal Institute of Technology, Stockholm, Sweden, 2012. TSC-MT 12-005.

3. Rose, J.G.; Teixeira, P.F.; Ridgway, N.E. Utilization of Asphalt/Bituminous Layers Coatings in Railway Track beds-A Compendium of International Applications. In Proceedings of the 2010 Joint Rail Conference JCR2010, Urbana, IL, USA, 27-29 April 2010.

4. Roberts, F.L.; Kandhal, P.S.; Brown, E.R.; Lee, D.Y.; Kennedy, T.W. Hot Mix Asphalt Materials, Mixture Design and Construction; National Asphalt Pavement Association Research and Education Foundation: Lanham, MD, USA, 1991.

5. European Asphalt Pavement Association. Asphalt in Railway Track. Retrieved from EAPA. 2014. Available online: https: / / eapa.org/wp-content/uploads/2018/07/2014.pdf (accessed on 29 December 2020).

6. RAIL.ONE. Ballastless Track Systems: Asphalt in Top Form, “Getrac Ballastless Track System”. Retrieved from RAIL.ONE. 2012. Available online: https:/ / www.railone.com/products-solutions/long-distance-and-freight-transport/ballastless-track-systems / getracr / (accessed on 29 December 2020).

7. Morscher, J. Slab Track Roadbeds in Germany-Implementation and Experience. In Proceedings of the AREMA Conference, Chicago, IL, USA, 12-15 September 1999.

8. Cardona, D.A.R. Characterization of Thermomechanical Properties of Bituminous Mixtures used for Railway Infrastructures. Ph.D. Thesis, University De Lyon, Lyon, France, 2016.

9. Rose, J.G.; Souleyrette, R.R. Asphalt Railway Trackbeds: Recent Designs, Apllications and Performances. In Proceedings of the American Railway Engineering and Maintenance-of-Way Association Conference, Minneapolis, MN, USA, 4-7 October 2015.

10. Freudenstein, S.; Liu, J.; Ren, J. The Development of High-Speed Railways in China and its Impact on the Chinese Economy. Eur. Railw. Rev. 2010, 2, 51-57. 
11. Ando, K.; Sunaga, M.; Aoki, H.; Haga, O. Development of Slab Tracks for Hokuriku Shinkansen Line. Q. Rep. RTRI 2001, 42, 35-41. [CrossRef]

12. Rose, J.G.; Teixeira, P.F.; Veit, P. International Design Practices, Applications, and Performances of Asphalt/Bituminous Railway Trackbeds. In Proceedings of the GEORAIL-International Symposium, Paris, France, 19-20 May 2011.

13. Sehgal, L.; Garg, A.; Sehgal, V. Hot mix asphalt in ballasted railway track: International experience and inferences. In Proceedings of the Institution of Permanent Way Engineers (IPWE) International Technical Seminar, 2017; Leykauf, G., Lechner, B., Eds.; Design of Ballastless Track Structures using Sleeper Panels Fixed on Concrete or Asphalt Pavements 2001; World Congress on Railway Research WCRR: Cologne, Germany, 2001.

14. Setiawan, D. Worldwide Slab Track Development as Consideration for Indonesian Slab Track Design Concept; University of Atma Jaya Yogyakarta: Yogyakarta, Indonesia, 2016.

15. European Asphalt Pavement Association (EAPA). Asphalt in Railway Tracks. EAPA Position Papers; European Asphalt Pavement Association: Breukelen, The Netherlands, 2003; pp. 5-11.

16. European Rail Infrastructure Managers (EIM). European Railway Technical Strategy, Technical Vision to Guide the Development of TSIs; Version 1.2; European Rail Infrastructure Managers: Brussels, Belgium, 2008.

17. Khabbaz, H.; Fatahi, B. How to Overcome Geotechnical Challenges in Implementing High Speed Rail Systems in Australia. Geotech. Eng. J. SEAGS AGSSEA 2014, 45, 39-47.

18. Diefenderfer, B.K. Crossing Recommendations for At-Grade Rail Crossings of U.S. Routes 19. and 15 in Prince William County, Virginia; VTRC 05-R12; Virginia Department of Transportation: Prince William County, VI, USA, 2005.

19. Rose, J.G. Selected In-Track Applications and Performances of Hot-Mix Asphalt Trackbeds. In Proceedings of the 2013 Joint Rail Conference, ASME Joint Rail Conference Knoxville, Knoxville, TN, USA, 15-18 April 2013. American Society of Mechanical Engineers Digital Collection.

20. Jerry, R.G.; Li, D.; Walker, L.A. Tests and evaluations of in-service asphalt trackbeds. In Proceedings of the American Railway Engineering \& Maintenance-of-Way Association Annual Conference, Washington, DC, USA, 22-25 September 2002.

21. Fang, F.; Qiu, Y.; Rose, J.G.; West, R.C.; Ai, C. Comparative analysis on dynamic behavior of two HMA railway substructures. J. Mod. Transp. 2011, 19, 26-34. [CrossRef]

22. Tayabji, S.D.; Bilow, D. Concrete Slab Track State of the Practice. Transp. Res. Rec. J. Transp. Res. Board 2001, 1742, 87-96. [CrossRef]

23. Rose, J.B. Asphalt Underlayment Railway Trackbeds: Design Applications, and Long-Term Performance Evaluations; 2017-UKY-R12b; National University Rail Centre-NURail, US DOT OST-R Tier 1 University Transportation Center: Urbana, IL, USA, 2017.

24. Capacity for Rail (C4R). Design Requirements and Improved Guidelines for Design (Track Loading, Resilience E Rams). Towards an Affordable, Resilient, Innovative and High-Capacity European Railway System for 2030/2050; European Union's Seventh Framework Program for Research, Technological Development and Demonstration: Cemosa, Spain, 2014.

25. Avramovic, N. Comparison of Ballast and Ballastless Track. Master's Thesis, Technical University Graz, Graz, Austria, 2010.

26. Gautier, P.-E. Slab track: Review of existing systems and optimization potentials including very high speed. Constr. Build. Mater. 2015, 92, 9-15. [CrossRef]

27. RAIL.ONE. Ballastless Track Systems: Top Performance on Firm Foundation, "Getrac Ballastless Track System". Retrieved from RAIL.ONE. 2012. Available online: https://www.railone.com/products-solutions/long-distance-and-freight-transport/ ballastless-track-systems / (accessed on 30 December 2020).

28. Miura, S.; Takai, H.; Uchida, M.; Fukada, Y. The Mechanism of Railway Tracks. Jpn. Railw. Transp. Rev. $1998,3,38-45$.

29. Sun, L.; Chen, L.; Zelelew, H.H. Stress and Deflection Parametric Study of High-Speed Railway CRTS-II Ballastless Track Slab on Elevated Bridge Foundations. J. Transp. Eng. 2013, 139, 1224-1234. [CrossRef]

30. Wang, F.; Liu, Z.; Wang, T.; Hu, S. A novel method to evaluate the setting process of cement and asphalt emulsion in CA mortar. Mater. Struct. 2007, 41, 643-647. [CrossRef]

31. Lei, X.; Zhang, B. Analysis of Dynamic Behavior for Slab Track of High-Speed Railway Based on Vehicle and Track Elements. J. Transp. Eng. 2011, 137, 227-240. [CrossRef]

32. Wang, F.; Liu, F.W.A.Y. The Compatibility and Preparation of the Key Components for Cement and Asphalt Mortar in High-Speed Railway. Reliab. Saf. Railw. 2012, 223. [CrossRef]

33. Wang, J.; Zhou, Y.; Wu, T.; Wu, X. Performance of Cement Asphalt Mortar in Ballastless Slab Track over High-Speed Railway under Extreme Climate Conditions. Int. J. Géoméch. 2019, 19, 04019037. [CrossRef]

34. Asphalt Institute. Mix Design Methods for Asphalt Concrete and other Hot-Mix Types. Manual No, 2 (MS-2), Lexington, KY. 1988. Available online: https:/ / pavementinteractive.org/reference-desk/design/mix-design/marshall-mix-design/ (accessed on 30 December 2020).

35. Lee, S.H.; Lee, J.W.; Park, D.W.; Hai, V.V. Evaluation of Asphalt Concrete for Railway Track. Constr. Build. Mater. 2014, 73, 13-18. [CrossRef]

36. Di Mino, G.; Di Liberto, M.; Maggiore, C.; Noto, S. A Dynamic Model of Ballasted Rail Track with Bituminous Sub-Ballast Layer. Procedia Soc. Behav. Sci. 2012, 53, 366-378. [CrossRef]

37. Cardona, D.R.; Di Benedetto, H.; Sauzeat, C.; Calon, N.; Saussine, G. Influence of Moisture Conditioning on Linear Viscoelastic Behaviour of Bituminous Mixtures Used for Railway Trackbeds. J. Test. Eval. 2017, 45, 40-50.

38. Hensley, M.J.; Rose, J.G. Design, Construction and Performance of Hot Mix Asphalt for Railway Trackbeds. In Proceedings of the 1st World Conference of Asphalt Pavements, Sydney, Australia, 20-24 February 2000. 
39. Soto, F.M.; Di Mino, G. Characterization of Rubberized Asphalt for Railways. Int. J. Eng. Sci. Res. Technol. 2018, 7, 284-303. [CrossRef]

40. Esmaeili, M.; Heydari-Noghabi, H.; Sayadi, A. Field investigation on the lateral resistance of railway tracks including hot mix asphalt layer. Road Mater. Pavement Des. 2016, 19, 154-166. [CrossRef]

41. Lee, S.-H.; Park, D.-W.; Vo, H.V.; Dessouky, S. Asphalt Mixture for the First Asphalt Concrete Directly Fastened Track in Korea. Adv. Mater. Sci. Eng. 2015, 2015, 1-6. [CrossRef]

42. Sol-Sánchez, M.; Pirozzolo, L.; Moreno-Navarro, F.; Rubio-Gamez, M. Advanced characterisation of bituminous sub-ballast for its application in railway tracks: The influence of temperature. Constr. Build. Mater. 2015, 101, 338-346. [CrossRef]

43. Bitume info No 32. 2015. Available online: https://www.eurobitume.eu/public_downloads/Magazines/bitume_info_32.pdf (accessed on 10 July 2020).

44. Yang, E.; Wang, K.C.P.; Luo, Q.; Qiu, Y. Asphalt Concrete Layer to Support Track Slab of High-Speed Railway. Transp. Res. Rec. J. Transp. Res. Board 2015, 2505, 6-14. [CrossRef]

45. French Tunneling and Underground Space Association AFTES. AFTES Recommendations Rail Track and Track Beds in Tunnels; GT40R2A1; French Tunnel Association and the Underground Space: Paris, France, 2013.

46. Liu, S.; Yang, J.; Chen, X.; Yang, G.; Cai, D. Application of Mastic Asphalt Waterproofing Layer in High-Speed Railway Track in Cold Regions. Appl. Sci. 2018, 8, 667. [CrossRef]

47. Yang, E.; Wang, K.C.P.; Qiu, Y.; Luo, Q. Asphalt Concrete for High-Speed Railway Infrastructure and Performance Comparisons. J. Mater. Civ. Eng. 2016, 28, 04015202. [CrossRef]

48. Soto, F.M.; Di Mino, G. Empirical Superpave Mix-Design of Rubberi-Modified Hot Mix Asphalt in Railway Sub-Ballast. Int. J. Civil Environ. 2017, 4. [CrossRef]

49. Fang, M.; Cerdas, S.F.; Qiu, Y. Numerical determination for optimal location of sub-track asphalt layer in high-speed rails. J. Mod. Transp. 2013, 21, 103-110. [CrossRef]

50. Selig, E.T.; Waters, J.M. Track Geotechnology and Substructure Management; Thomas Telford Publications: London, UK, 1994.

51. Adam, D.; Brandl, H.; Paulmichl, I. Dynamic aspects of rail tracks for high-speed railways. Int. J. Pavement Eng. 2010, 11, 281-291. [CrossRef]

52. Hwang, D.; Witczak, W. Program DAMA (Chevron), User's Manual; Department of Civil Engineering, University of Maryland: College Park, MD, USA, 1979.

53. Asphalt Institute. Research and Development of the Asphalt Institute's Thickness Design Manual, 9th ed.; Research Report No. 82-2; Asphalt Institute: Lexington, KY, USA, 1982.

54. Hay, W.W. Railroad Engineering, 2nd ed.; John Wiley \& Sons: Hoboken, NJ, USA, 1982.

55. Kerr, A.D. The determination of the track modulus $\mathrm{k}$ for the standard track analysis. In Proceedings of the 2002 American Railway Engineering and Maintenance-of-Way Association Annual Conference, Washington, DC, USA, 22-25 September 2002.

56. McHenry, M.T.; Rose, J.G. Railroad Subgrade Support and Performance Indicators; Report No. KTC-12-02/FR 136-04-6F; Kentucky Transportation Cabinet: Frankfort, KY, USA, 2012.

57. Lechner, B. Design and Layout of Ballastless Track Systems Using Unbound Base Course Layers; International Union of Railways: Seoul, Korea, 2008.

58. Lechner, B. Railway Concrete Pavements. In Proceedings of the 2nd International Conference on Best Practices for Concrete Pavements, Florianopolis, Brazil, 2-4 November 2011.

59. Teixeira, P.F.; López-Pita, A.; Casas, C.; Bachiller, A.; Robusté, F. Improvements in High-Speed Ballasted Track Design: Benefits of Bituminous Subballast Layers. Transp. Res. Rec. J. Transp. Res. Board 2006, 1943, 43-49. [CrossRef]

60. Buonanno, A.; Mele, R. The use of Bituminous Mix Sub-Ballast in the Italian State Railways. In Proceedings of the Papers submitted for view at 2nd Eurasphalt and Eurobitume Congrese, Barcelona, Spain, 20-22 September 2000.

61. Lechner, B. General Requirements for Ballastless Rail-Trackforms Asphalt and Concrete Pavement Design. In Proceedings of the International Journal of Pavement Conference, IJPC, Sao Paulo, Brazil, 9-10 December 2013.

62. Esveld, C. "Modern Railway Track", MRT-Productions, 2nd ed.; TU Delft: Zaltbommel, The Netherlands, 2001.

63. Huang, Y.H.; Lin, C.; Rose, J.G. Asphalt Pavement Design: Highway versus Railroad. J. Transp. Eng. 1984, 110, 276-282. [CrossRef]

64. Huang, Y.H.; Lin, C.; Deng, X. Hot Mix Asphalt for Railroad Trackbeds-Structural Analysis and Design. Assoc. Asph. Paving Technol. Proc. 1984, 53, 475-494.

65. Fang, M.; Qiu, Y.; Ai, C.; Wei, Y. Gradation Determination of Impermeable Asphalt Mix on Subgrade Surface Layer for Ballastless Track in High-Speed Railway Lines. In ICTE 2011; American Society of Civil Engineers (ASCE): Reston, VA, USA, 2011; pp. 1926-1931.

66. Cardona, D.R.; Di Benedetto, H.; Sauzeat, C.; Calon, N.; Saussine, G. Use of a bituminous mixture layer in high-speed line track beds. Constr. Build. Mater. 2016, 125, 398-407. [CrossRef]

67. Momoya, Y.; Horiike, T.; Ando, K. Development of Solid Bed Track on Asphalt Pavement. Q. Rep. RTRI 2002, 43, 113-118. [CrossRef]

68. Teixeira, P.F.; Ferreira, P.A.; López Pita, A.; Casas, C.; Bachiller, A. The Use of Bituminous Subballast on Future High-Speed lines in Spain: Structural Design and Economical Impact. Int. J. Railw. 2009, 2, 1-7. 
69. Beecken, G. Practical Trial of an Asphalt Railroad Bed with Y-Shaped Sleepers. Final Report. Retrieved from Transportation Research International Documentation, National Technical Information Service. 30 November 1988. Available online: https: / / trid.trb.org/view/286356 (accessed on 30 December 2020).

70. Rose, J.G.; Konduri, K. KENTRACK-A Railway Trackbed Structural Design Program. In Proceedings of the AREMA 2006 Annual Conference, Louisville, KY, USA, 17-20 September 2006.

71. Rose, J.G.; Liu, S.; Souleyrette, R.R. KENTRACK 4.0: A Railway Trackbed Structural Design Program. In Proceedings of the 2014 Joint Rail Conference, Colorado Springs, CO, USA, 2-4 April 2014.

72. Ramirez, D.; Benkahla, J.; D’Aguiar, S.C.; Calon, N.; Robinet, A.; Di Benedetto, H.; Sauzeat, C. High-Speed Ballasted Track Behaviour with Sub-Ballast Bituminous Layer. In Proceedings of the International Symposium on Geotechnical Railway, GeoRail, Morne-La-Vallee, France, 6-7 November 2014.

73. Esmaeili, M.; Amiri, S.; Jadidi, K. An investigation into the use of asphalt layers to control stress and strain levels in railway track foundations. Proc. Inst. Mech. Eng. Part F J. Rail. Rapid Transit. 2012, 228, 182-193. [CrossRef]

74. Huang, H.; Shen, S.; Tutumluer, E. Sandwich Model to Evaluate Railroad Asphalt Trackbed Performance under Moving Loads. Transp. Res. Rec. J. Transp. Res. Board 2009, 2117, 57-65. [CrossRef]

75. Soto, F.M.; Di Mino, G.; Di Liberto, C. Evaluation of Dry Asphalt Rubber Concrete in Railway Sub-Ballast using the Four Point Bending Test. In Proceedings of the The Third International Conference on Railway Technology: Research, Development and Maintenance; Civil-Comp Press: Stirlingshire, UK, 2016; Volume 110.

76. Soto, F.M.; Di Mino, G. Procedure for a Temperature-Traffic Model on Rubberized Asphalt Layers for Roads and Railways. J. Traffic Transp. Eng. 2017, 5, 171-202. [CrossRef]

77. Ižvolt, L.; Šmalo, M. Historical Development and Applications of Unconventional Structure of Railway Superstructure of the Railway Infrastructure of the Slovak Republic. Civ. Environ. Eng. 2014, 10, 79-94. [CrossRef]

78. Esveld, C. Innovations in Railway Track; TU Delft: Delft, Holland, 1997.

79. Alfaro, S.; Montalban, L.; Villalba, I.; Herraiz, J.; Segarra, A. An Environmentally Friendly Railway Crumb Rubber Modified Bitumen for Sub-Ballast Layer. In Proceedings of the 9th World Congress on Railway Recearch, WCRR, Lille, France, 22-26 May 2011.

80. Sañudo, R.; Cerrada, M.; Alonso, B.; Dell'Olio, L. Analysis of the influence of support positions in transition zones. A numerical analysis. Constr. Build. Mater. 2017, 145, 207-217. [CrossRef]

81. Wilk, S.T.; Stark, T.; Rose, J.G. Evaluating tie support at railway bridge transitions. Proc. Inst. Mech. Eng. Part F J. Rail. Rapid Transit. 2015, 230, 1336-1350. [CrossRef]

82. Coelho, B.; Priest, J.; Holscher, P.; Powrie, W. Monitoring of Transition Zones in Railways; Railway Engineering, Engineering Technics Press: London, UK, 2009.

83. Li, D.; Davis, D. Transition of Railroad Bridge Approaches. J. Geotech. Geoenvironmental. Eng. 2005, 131, 1392-1398. [CrossRef]

84. Kerr, A.D.; Bathurst, L.A. A Method for Upgrading the Performance at Track Transitions for High-Speed Service (No. DOT/FRA/RDV02/05); Federal Railroad Administration: Cambridge, MA, USA, 2001.

85. Sañudo, R.; Dell'Olio, L.; Casado, J.; Carrascal, I.; Diego, S. Track transitions in railways: A review. Constr. Build. Mater. 2016, 112, 140-157. [CrossRef]

86. Transit Cooperative Research Program; Transportation Research Board. Design of Track Transitions. Natl. Acad. Sci. Eng. Med. 2006, 79. [CrossRef]

87. Tutumluer, E.; Stark, T.D.; Mishra, D.; Hyslip, J.P. Investigation and Mitigation of Differential Movement at Railway Transitions for US High Speed Passenger Rail and Joint Passenger/Freight Corridors. In Proceedings of the 2012 Joint Rail Conference; ASME International: Philadelphia, PA, USA, 2012; pp. 75-84.

88. Yu, Z.; Connolly, D.; Woodward, P.; Laghrouche, O. Settlement behaviour of hybrid asphalt-ballast railway tracks. Constr. Build. Mater. 2019, 208, 808-817. [CrossRef]

89. D'Angelo, G.; Thom, N.; Presti, D.L. Bitumen stabilized ballast: A potential solution for railway track-bed. Constr. Build. Mater. 2016, 124, 118-126. [CrossRef]

90. Kucera, P.; Lidmila, M.; Jasansky, P.; Pycha, M.; Burrow, M.P.; Ghataora, G.S. The feasibility of using asphalt concrete with a high percentage of recycled asphalt material in a railway trackbed layer. Transp. Geotech. 2021, 26, 100429. [CrossRef]

91. Lazorenko, G.; Kasprzhitskii, A.; Khakiev, Z.; Yavna, V. Dynamic behavior and stability of soil foundation in heavy haul railway tracks: A review. Constr. Build. Mater. 2019, 205, 111-136. [CrossRef]

92. Khairallah, D.; Blanc, J.; Hornych, P.; Piau, J.-M.; Cottineau, L.-M.; Pouget, S.; Ducreau, A.; Savin, F.; Hosseingholian, M. Influence of the Bituminous Layer on Temperature and Water Infiltration in Railway Structures of the Bretagne-Pays de la Loire High-Speed Line. J. Test. Eval. 2019, 48, 134-149. [CrossRef]

93. Khairallah, D.; Blanc, J.; Cottineau, L.M.; Hornych, P.; Piau, J.-M.; Pouget, S.; Hosseingholian, M.; Ducreau, A.; Savin, F. Monitoring of railway structures of the high speed line BPL with bituminous and granular sublayers. Constr. Build. Mater. 2019, 211, 337-348. [CrossRef]

94. Hosseingholian, M. Railenium: A New Technological Research Institute for Railway Infrastructure, Rolling Stock and Systems. Railnium Working Program. 2016. Available online: https://railenium.eu/wp-content/uploads/2016/08/REVES-UK.pdf (accessed on 10 July 2020). 
95. D'Angelo, G.; Presti, D.L.; Thom, N.H. Optimisation of bitumen emulsion properties for ballast stabilisation. Mater. Construcción 2017, 7, 124. [CrossRef]

96. Sol-Sánchez, M.; D'Angelo, G. Review of the design and maintenance technologies used to decelerate the deterioration of ballasted railway tracks. Constr. Build. Mater. 2017, 157, 402-415. [CrossRef]

97. D’Angelo, G.; Sol-Sánchez, M.; Moreno-Navarro, F.; Presti, D.L.; Thom, N. Use of bitumen-stabilised ballast for improving railway trackbed conventional maintenance. Géotechnique 2018, 68, 518-527. [CrossRef]

98. D'Angelo, G.; Bressi, S.; Giunta, M.; Gallego, J.; Thom, N. Novel performance-based technique for predicting maintenance strategy of bitumen stabilised ballast. Constr. Build. Mater. 2018, 161, 1-8. [CrossRef]

99. D'Angelo, G. Bitumen Stabilised Ballast: A Novel Track-Bed Solution towards a More Sustainable Railway. Ph.D. Thesis, University of Nottingham, Nottingham, UK, 2018.

100. Jing, G.; Qie, L.; Markine, V.L.; Jia, W. Polyurethane reinforced ballasted track: Review, innovation and challenge. Constr. Build. Mater. 2019, 208, 734-748. [CrossRef]

101. Thompson, D.R.; Woodward, P.K. Track stiffness management using the XiTRACK GeoComposite. J. Perm. Way Inst. 2004, 122, 135-139.

102. Remennikov, A.M.; Kaewunruen, S. A review of loading conditions for railway track structures due to train and track vertical interaction. Struct. Control Health Monit. Off. J. Int. Assoc. Struct. Control Monit. Eur. Assoc. Control Struct. 2008, 15, 207-234. [CrossRef]

103. Bose, T.; Zania, V.; Levenberg, E. Experimental investigation of a ballastless asphalt track mockup under vertical loads. Constr. Build. Mater. 2020, 261, 119711. [CrossRef]

104. Yusupov, B.; Qiu, Y.; Ding, H.; Rahman, A. Temperature and material behaviour effects on dynamic responses of asphalt concrete trackbed. Int. J. Rail Transp. 2019, 8, 66-79. [CrossRef]

105. Gao, L.; An, B.; Xin, T.; Wang, J.; Wang, P. Measurement, analysis, and model updating based on the modal parameters of high-speed railway ballastless track. Measurement 2020, 161, 107891. [CrossRef]

106. Yang, J.; Chen, X.; Ma, Y.; Yang, J.; Cai, D.; Yang, G. Modelling and in-situ measurement of dynamic behavior of asphalt supporting layer in slab track system. Constr. Build. Mater. 2019, 228, 116776. [CrossRef]

107. Sainz-Aja, J.; Pombo, J.; Tholken, D.; Carrascal, I.; Polanco, J.; Ferreño, D.; Casado, J.; Diego, S.; Perez, A.; Abdala Filho, J.E.; et al. Dynamic calibration of slab track models for railway applications using full-scale testing. Comput. Struct. 2020, 228, 106180. [CrossRef]

108. Wehbi, M.; Gallou, M.; Lee, B. Towards trackbed design with asphalt underlayment using FWD-based numerical model. Int. J. Rail Transp. 2019, 8, 370-386. [CrossRef]

109. Yang, J.; Chen, X.; Yang, J.; Cai, D.; Yang, G. Numerical study and in-situ measurement of temperature features of asphalt supporting layer in slab track system. Constr. Build. Mater. 2020, 233, 117343. [CrossRef]

110. Zhou, J.; Chen, X.; Zhou, J.; Xu, G.; Cai, D. Dynamic Responses of Asphalt Concrete Waterproofing Layer in Ballastless Track. Appl. Sci. 2019, 9, 375. [CrossRef]

111. Liu, S.; Yang, J.; Chen, X.; Wang, M.; Zhou, W. Design of Asphalt Waterproofing Layer for High-Speed Railway Subgrade: A Case Study in Heilongjiang Province, China (No. 17-03098). In Proceedings of the Transportation Research Board 96th Annual Meeting, Washington, DC, USA, 8-12 January 2017.

112. Wang, Z.; Yang, J.; Chen, X. Mastic Asphalt Concrete Waterproof Layer on High-Speed Railway Subgrade in Cold Regions (No. 15-2450). In Proceedings of the Transportation Research Board 94th Annual Meeting, Washington, DC, USA, 11-15 January 2015.

113. Lee, S.-H.; Choi, Y.-T.; Lee, H.-M.; Park, D.-W. Performance evaluation of directly fastened asphalt track using a full-scale test. Constr. Build. Mater. 2016, 113, 404-414. [CrossRef]

114. Lee, S.H.; Vo, H.V.; Park, D.W. Investigation of Asphalt Track Behaviour Under Cyclic Loading: Full-Scale Testing and Numerical Simulation. J. Test. Eval. 2017, 46, 934-942.

115. Le, T.H.M.; Lee, S.-H.; Park, D.-W. Evaluation on full-scale testbed performance of cement asphalt mortar for ballasted track stabilization. Constr. Build. Mater. 2020, 254, 119249. [CrossRef]

116. Lee, S.-H.; Park, D.-W.; Vo, H.V.; Fang, M. Analysis of asphalt concrete track based on service line test results. Constr. Build. Mater. 2019, 203, 558-566. [CrossRef]

117. Martínez-Soto, F.; Di Mino, G. The Resistance to Fatigue of Dry Asphalt Rubber Concrete for Sub-Ballast Layer. In Proceedings of the 15th International Conference of Railway Engineering, Madrid, Spain, 19-21 July 2016.

118. Soto, F.M.; Di Mino, G. Optimization of the Mix-Design System for the Sub-Ballast Raiload. J. Traffic Transp. Eng. 2017, 5, 246-259.

119. Wang, J.; Zeng, X. Influence of Temperature and Pressure on the Dynamic Properties of Rubber-Modified Asphalt Concrete. J. Mater. Civ. Eng. 2006, 18, 125-131. [CrossRef]

120. Zhong, X.G.; Zeng, X.; Rose, J.G. Shear Modulus and Damping Ratio of Rubber-modified Asphalt Mixes and Unsaturated Subgrade Soils. J. Mater. Civ. Eng. 2002, 14, 496-502. [CrossRef]

121. Kim, H.-S.; Lee, S.-J.; Amirkhanian, S. Rheology investigation of crumb rubber modified asphalt binders. KSCE J. Civ. Eng. 2010, 14, 839-843. [CrossRef]

122. Yildirim, Y. Polymer Modified Asphalt Binders. Constr. Build. Mater. 2007, 21, 66-72. [CrossRef]

123. Yang, J.; Kong, B.; Cai, C.; Wang, J.S. Behavior of High-Speed Railway Ballastless Track Slabs Using Reactive Powder Concrete Materials. J. Transp. Eng. 2016, 142, 4016031. [CrossRef] 
124. Qiu, K.; Chen, H.; Ye, H.; Hong, J.; Sun, W.; Jiang, J. Thermo-Mechanical Coupling Effect on Fatigue Behaviour of Cement Asphalt Mortar. Int. J. Fatigue. 2013, 51, 116-120. [CrossRef]

125. Shuguang, H.; Yunhua, Z.; Fazhou, W. Effect of temperature and pressure on the degradation of cement asphalt mortar exposed to water. Constr. Build. Mater. 2012, 34, 570-574. [CrossRef]

126. Wang, F.; Liu, Z.; Hu, S. Early age volume change of cement asphalt mortar in the presence of aluminum powder. Mater. Struct. 2010, 43, 493-498. [CrossRef]

127. Momoya, Y.; Sekine, E. Reinforced Roadbed Deformation Characteristics Under Moving Wheel Loads. Q. Rep. RTRI 2004, 45, 162-168. [CrossRef]

128. Momoya, Y.; Sekine, E.; Tatsuoka, F. deformation characteristics of RAILWAY roadbed and subgrade under moving-wheel load. Soils Found. 2005, 45, 99-118. [CrossRef]

129. Momoya, Y. New Railway Roadbed Design. Railw. Technol. Avalanche 2007, 20, 118.

130. Ren, J.; Wang, J.; Li, X.; Wei, K.; Li, H.; Deng, S. Influence of cement asphalt mortar debonding on the damage distribution and mechanical responses of CRTS I prefabricated slab. Constr. Build. Mater. 2020, 230, 116995. [CrossRef]

131. Li, T.; Su, Q.; Kaewunruen, S. Influences of dynamic material properties of slab track components on the train-track vibration interactions. Eng. Fail. Anal. 2020, 115, 104633. [CrossRef]

132. Rutherford, T.; Wang, Z.; Shu, X.; Huang, B.; Clarke, D.R. Laboratory investigation into mechanical properties of cement emulsified asphalt mortar. Constr. Build. Mater. 2014, 65, 76-83. [CrossRef]

133. Yuan, Q.; Liu, W.; Pan, Y.; Deng, D.; Liu, Z. Characterization of Cement Asphalt Mortar for Slab Track by Dynamic Mechanical Thermoanalysis. J. Mater. Civ. Eng. 2016, 28, 04015154. [CrossRef]

134. Ouyang, J.; Zhao, J.; Tan, Y. Modeling mechanical properties of cement asphalt emulsion mortar with different asphalt to cement ratios and temperatures. J. Mater. Civil Eng. 2018, 30, 04018263. [CrossRef]

135. Su, M.; Dai, G.; Peng, H. Bond-slip constitutive model of concrete to cement-asphalt mortar interface for slab track structure. Struct. Eng. Mech. 2020, 74, 589-600.

136. Le, T.H.M.; Park, D.-W.; Seo, J.-W. Evaluation on the mechanical properties of cement asphalt mortar with quick hardening admixture for railway maintenance. Constr. Build. Mater. 2019, 206, 375-384. [CrossRef]

137. Li, Y.; Chen, J.; Wang, J.; Shi, X.; Chen, L. Analysis of Damage of Joints in CRTSII Slab Track under Temperature and Vehicle Loads. KSCE J. Civ. Eng. 2020, 24, 1209-1218. [CrossRef]

138. Zhang, Y.; Wu, K.; Gao, L.; Yan, S.; Cai, X. Study on the interlayer debonding and its effects on the mechanical properties of CRTS II slab track based on viscoelastic theory. Constr. Build. Mater. 2019, 224, 387-407. [CrossRef]

139. Peng, H.; Zhang, Y.; Wang, J.; Liu, Y.; Gao, L. Interfacial Bonding Strength between Cement Asphalt Mortar and Concrete in Slab Track. J. Mater. Civ. Eng. 2019, 31, 04019107. [CrossRef]

140. Esveld, C. Track Structures in Urban Environment; Symposium K.U.: Leuven, Belgium, 1997.

141. Urban Track. Urban Rail Transport. In European Community, Sustainable Development, Global Changes E Ecosystems; TIP5-CT-2006032312; European Community under the Sixth Framework Program: Madrid, Spain, 2008.

142. RAIL.ONE. Ballastless Track Systems: Bringing Green to Track systems, "ATD-G City Green Tracks". Retrieved from RAIL.ONE. 2011. Available online: https:/ / www.railone.com/fileadmin/daten/05-presse-medien/downloads/broschueren/en/Green_ tracks_EN_2011_ebook.pdf (accessed on 29 December 2020).

143. Van de Ven, M.F.C.; Huurnan, M.; Dijkink, J.; Heerkens, J.; Groene-Boom, L.H.; Van de Linen, B. Embeded Rail in Asphalt (ERIA). In Proceedings of the Third Eurasphalt and Eurobitumen Congress, Vienna, Austria, 12-14 May 2004; Volume 1.

144. Huurman, M.; Markine, V.L.; De Man, A.P. Design Calculations for Embedded Rail in Asphalt. Transp. Res. Rec. J. Transp. Res. Board. 2003, 1825, 28-37. [CrossRef] 